\title{
The Articulation of Migrant Spatiality in Kureishi's Cinema: Revisiting My Beautiful Launderette
}

Sri Lanka Journal of Social Sciences and Humanities Volume 1 Issue 2, August 2021: 27-35 ISSN: 2773 692X (Online), 27736911 (Print) Copyright: (C) 2021 The Author(s)

Published by Faculty of Social Sciences and Languages, Sabaragamuwa University of Sri Lanka Website: https://www.sab.ac.lk/sljssh DOI: http://doi.org/10.4038/sljssh.v1i2.35

\author{
Jayakody, J.M.A.K. ${ }^{1{ }^{*}}$ and Hapugoda, H.A.M.A. ${ }^{1}$ \\ ${ }^{1}$ Department of Languages, Sabaragamuwa University of Sri Lanka, Belihuloya, 70140, Sri Lanka.
}

Received: 03 December, 2020, Revised: 28 March, 2020, Accepted: 26 April, 2021.

How to Cite this Article: Jayakody, J.M.A.K. and Hapugoda, H.A.M.A. (2021). The Articulation of Migrant Spatiality in Kureishi's Cinema: Revisiting My Beautiful Launderette. Sri Lanka Journal of Social Sciences and Humanities, 1(2), 27-35.

\begin{abstract}
As a legacy of colonization, the Third World's fantasy of the West as a utopia of welcoming melting pot with innumerable wealth had nurtured identifications of drastic immigrant influx to metropolitan centers. But their quest for unique spatiality in the Centre was often challenged by catastrophic ordeals that expatriates happened to undergo there. In this context, this paper argues that Hanif Kureishi as a Pakistani cinematographer with tangible experiences has been able to successfully depict the migrants' quest of a new spatiality in 'My Beautiful Launderette' (1989). This literary analysis is qualitative in nature and it deploys theoretical interpretations of Mitchel Foucault and Henry Lefebvre to discover the nature of that spatiality. According to findings of the study, immigrants' quest of spatiality with their geographical dislocation from the periphery to the Centre had been challenged by their fluctuation in between the native territory and the host locale. The dual existence amidst the migrant turbulence upsized multiple spatiality that immigrants have entrapped within varied trajectories of the ideological shift of Pakistani expatriates within the socio - cultural transition. The controversial socio-political upheavals under Margret Thatcher had not only undermined immigrants' inclinations to find a unique identity and space with wealth accumulation and embracing western notions but greatly disturbed their fantasy of progress. Expatriates' incapability to locate themselves in the center owing to prevalent racial polarizations had intensely traumatized their psychology to embrace traditional values. Similarly, such psychological dislocation can be ubiquitously relatable to the Sri Lankan sphere.
\end{abstract}

Keywords: Expatriates, Hanif Kureishi, Migrant cinema, Postcolonial spatiality

\section{INTRODUCTION}

Postcolonialism is an intellectual discourse that evolved to articulate the voice of suppressed postcolonial subjects. It used the cultural inheritance of the colonial master to reidentify the location of the subject and its new relationship to the master. Migrant literature as a sub-genre that emerged as a positive reaction owing to cultural, socio- political and historical outbursts in Postcolonialism upsized varied conceptions and complications undergone by $\mathrm{mi}-$ grants. By the 1960s, the drastic paradigm shift in British culture manipulated a huge number of immigrants to migrate from the Centre to periphery in quest for progress in a land of plenty. The deep desire for this de-territorialization is broadly termed as pursuing the Eurocentric fantasy ( $\mathrm{Ha}$ pugoda, 2016). The inculcated notion of territorial mobility from periphery to the Centre for the acquisition of capital, which the periphery is devoid of, led to a drastic pour of coIonial non- White immigrants to Europe. By the 1980s the depiction of migration in artistic and literary creations was a lucrative income with a vocational backdrop. The emergence of migrant cinema as a socio-aesthetic cinematography explored new migrations from Africa, Middle East, and South East Asia to both western and non-western terri- tories through the intervention of migrant population in relation to contemporary historical, cultural, and political turmoil.

As per Michelle Balaev, geographical dislocation has the tendency to inculcate a deep-rooted traumatic experience in migrants in exploring their migrant spatiality.

"Descriptions of the geographic place of traumatic experience and remembrance situate the individual in relation to a larger cultural context that contains social values that influence the recollection of the event and the reconfiguration of the self. The primacy of place in the representation of trauma anchors the individual experience within a larger cultural context, and, in fact, organizes the memory, meaning and trauma."

(Balaev, 2000)

The conceptualization of the 'spatiality' or 'heterotopia' was first characterized by Mitchel Foucault in his lecture 'Of other Spaces' in 1967 that amalgamated in the arena of architecture. The concept was defined as;

"Practical disinfection of space."

(Foucault, 1967)

The conceptualization of the multiple specialties or heterotopias reinforced the fluctuation of migrants past self of the

\footnotetext{
* Corresponding author: Tel.: +94 (71) 269 6008; Email: ashajayakody511@gmail.com

(D) https://orcid.org/0000-0002-6168-9660
} 
native entity with the new space. In a cultural realm, the concept referred to alternative spaces generated within an individual's encounter with the real. In defining themselves in the west, the geographical position was in conflict with the Postcolonial geo- position.

Hanif Kureishi as an epitome of expatriates who migrated from the postcolonial periphery to the metropolitan Centre obviously resembles traumatic experiences of migration through his cinematography. The researchers intend to choose Hanif Kureishi as the applicable cinematographer to explore the trauma of migrant spatiality owing to his tangible experiences as a Pakistani expatriates and realistic portrayals of these catalysts through his movies. The researchers have chosen 'My Beautiful Launderette', that is unique to explore the thematic considerations in different perspectives. As per the diversity of Kureishi's outlook on migrant experience, the researchers intend to unravel selected notions through this literary creation. The way Kureishi had undergone ordeals within the 1960's British backdrop as a Pakistani immigrant, his journey to Pakistan later had become a catalyst for the exploration of a proper identity, and his dilemma of migration had skillfully demonstrated through his cinematography. Kureishi's own dilemmas of migration had depicted and he further exposes the difficulty to overcome the psychological dislocation owing to migration.

In relation to aims of the study, the primary objective of this paper is to unravel diversified spatiality that a postcolonial migrant will explore in an alien land that showed new avenues for survival. The researchers intend to reinforce migrant spatiality in a dualistic perspective. In a microcosmic view, the research is aimed to articulate both inner and outward catalysts that affect trauma of migrants from the third world which resulted in the identity crisis and the sense of displacement along with aloofness in those novice backdrops. Through the macrocosmic identification, this paper intends to explore migrant spatiality as a postcolonial disorder followed by the traumatized entities of memory, history and the trauma of mobility from the periphery of limited choices to the Centre in quest of better prospects. As secondary objectives, the research aims on exploring migration in a phantasmic layer through the dualistic portrayal of the western fantasy of exoticism and eastern fantasy of a utopia of wealth and capital. The influence of Thatcherism and the transformation followed by the economic outburst is explored and its direct and indirect influence on expatriates' multiple spatiality is further examined by the researcher. Furthermore, the possibility of identifying trauma through double-marginalization on expatriates are examined in the research.

\section{LITERATURE REVIEW}

In reviewing the available literature of the concept, Ruth Maxley's Commonwealth Journal publication of 'Life in the Diaspora in a Strong Suspension through the First-generation Immigrants is an Exploration of Home and Return' was a renowned publication of Hanif Kureishi's cinematographic articulations of the migrant fantasy of expatriates. Maxley's article on life in the diaspora interlaced with the notion of 'home' and 'return' mainly reinforced through both male and female expatriates of the first generation. The conceptual background of 'home' and 'return' assigned on both domestic and national sphere while Maxey depicts the ideology of return through Kureishi's cinema.

Maxey powerfully depicts the migrant fantasy of Pakistani immigrants and their liabilities of acquiring desired notions through migrating. He encapsulates the consideration of 'home' and 'return' and the identification of Britain as a temporary stop- over.

In 2013, Andreas Athanasiades's scholarly article on 'Re-imagining desire and sexuality in the cinema of Hanif Kureishi' encapsulates diversified manifestations of positive and negative counter-reactions related to the Eurocentric fantasy of Pakistani immigrants. The dialectical manifestation of characters: Asian-British, Periphery-Centre, East-West and in home and exile intensify the blurring of these polarizations in characters' quest for desire and sexuality. The binaries achieved not in a way of deviating from differentiations yet through the reconciliation of biases that predominantly explored by the homosexual intimacy of Omar and Johnny to culmination of their desire and sexuality as a counterpart of racial-cultural outbursts and stigmas and dogmas inculcated.

Omar's characterization as varied implications of desire and sexuality by his change of the name the launderette from 'Churchill' to 'Powders' that directly connotes the arena that nurtured his homosexual aspirations. Tania's structural marginalization in Britain and her rebellious deed of challenging stereotypical façade of females in both cultures is utilized. Her entrapment within Omar's homosexual romantic triangle articulates her female diasporic subjectivity. Her exodus is controversial in the movie that is outspoken of her sexual liberty and freedom in the patriarchal regime.

However, the articulation of migrant spatiality of Kureshi's cinema in relation to Hanif Kureishi's 'My Beautiful Launderette' has not been conducted yet. A plethora of research had attributed in depicting the migrant fantasy and the Eurocentric fantasy of Pakistani immigrants interlaced to Thatcherism in Britain. In the research, the researcher intends to reinforce the diversified perspectives of multiple migrant heterotopias of Pakistani expatriates with the mobility of migrants from periphery to the center. The amalgamation of Foucault and Henry Lefebvre's conceptualization of spatiality into the study, the researcher identifies a unique dimension of depicting the psychoanalytical perspective of migration. In utilizing Literary analysis and textual analysis as applicable methodologies to explore the conceptualization the researcher intends to derive a comparative interpretation on the selected sample to present a vivid and wider manifestation to the research problem with a new outlook to the research problem. It explores the impact of migration with catalysts that influence self's comprehension of a migrant spatiality and the way that experience shaped in Kureishi's cinema that display insights into the identity and the unconscious affected by the consequences of migration that obviously regenerates a pathway for future research implications.

\section{METHODOLOGY}

The research is predominantly qualitative in nature that exposes migrant spatiality in a postcolonial spectrum with regard to tendencies adhered to the sphere of migrants in the third world. As the research reinforces an in-depth articulation of multiple spaces of migrant experience related to $\mathrm{Pa}$ kistani expatriates effectively in Hanif Kureishi's selected cinematography, the researcher intends to utilize qualitative research paradigm as the suitable methodology to investigate the research problem. Rather than a quantitative approach, a qualitative methodology is taken into considera- 
tion as the research exposes a Humanitarian crisis that eventually requires individual attributions and opinions to delve in to the subject matter for substantial research findings.

In order to excavate in-depth explanations to the concept of Spatiality in a Postcolonial appeal of migration, the researcher utilized in-depth interpretations of Hanif Kureishi's 'My Beautiful Launderette'. In data analysis and interpretation, the researcher employs Literary Analysis and Textual Analysis in the interpretation of the selected movie. These methods involve the underline elaboration of characterization, their rapports with each other, the depiction of multiple space through respective dialogues in movies as visible evidences of Pakistani expatriates' dilemmas of residing in locales of western hegemony inculcated with their racialcultural discrepancies and traumas of memory and history. The researchers employed Hanif Kureishi's 'My Beautiful Launderette' evidenced migrant's catastrophic outbursts in the center through versatile dimensions that directed the study into a broader spectrum.

\section{RESULTS AND DISCUSSION}

Kureishi's Articulation of the Migrant Spatiality: Migrant cinema is a novice approach in cinema's legacy that depicts controversial dimensions that expatriates undergo within contours of migration. In that regard, Hanif Kureishi as an offspring of hybrid parentage and with tangible experiences of migrant turbulence skillfully upsize dilemmas of migration in his cinema. Kureishi reinforces the epoch of the culmination of migration to Britain from 1960 to the booming Islam fundamentalism as landmarks of migrants' quest of identity, marginalization and subordinations in the west. As migration from periphery to the Centre in quest of better prospects that the periphery is devoid of, is increasing day by day, the researcher's attempt is to upsize ordeals undergone by Pakistani expatriates in re-defining their identity and unique spatiality in the west that articulates an omnipresent and ubiquitous concept to entire denizens of the third world including Sri Lanka.

The Complexity of the Spatial Engagement of Migrants in the Centre: Migration from east to west as disciples of the third world is traumatized for migrants with their dislocation from the native landscape and implanting themselves in the novice backdrop led to their sense of not belonging within both entities. In achieving their migrant fantasy of superiority in the west, expatriates completely objectified in their western dream. By the close affiliation to the decolonization, the colonial master had abandoned the deep-rooted immigrant's superiority of the west as the ideal place for the acquisition of their financial dream. The dual existence amidst the migrant turbulence upsized multiple spatiality that immigrants have entrapped within diversified junctures of migration. The movie, 'My Beautiful Launderette' reinforces varied trajectories of the ideological shift of Pakistani expatriates within the socio - cultural transition.

As per Foucault,

"In any case I believe that the anxiety of our era has to do fundamentally with space, no doubt a great deal more than time. Time probably appears to us as one of the various distributive operations that are possible for the elements that are spread out in space."

(Foucault, 1986)

Migrants and Cultural Heterotopia: The migrants move between different cultural space and time as they change their location across civilizations. When they speak from their new location, often they unavoidably speak of their former space with a touch of nostalgia. They are psychological travelers between two worlds and, as a result, their present experience becomes hyperreal. According to Foucault's identification, time and history erect a multiplicity of realistic dimensions upsized by time and space. The notion of immigrants' inclination to migrate to the Centre recreates an outburst of Cultural Heterotopologic consequences that makes the migrant situation hectic and full of ordeals. Pakistani expatriates' fluctuation in between the acquisition of their Eurocentric dream of material advancement is parallel to their incapability to deny Pakistani roots.

"Heterotopias are 'real' spaces beyond familiar realities. They exist at the 'border', 'margin' or 'periphery' of a society, and from there at a distance, unlike the 'utopias', they determine and conditions all the other remaining spaces. They are the 'other spaces' indeed that inform the 'self' of the society.'

(Foucault, 1986)

The movie characterizes the duality of migrant spatiality of the third world expatriates. In the journey of negotiation spatial differentiation of their Pakistani identity and eastern upbringing, expatriates undergo a process of imaginary remapping that they decide to embrace the western identifications with the material advancement. According to Henry Lefebvre, Cultural Heterotopology depicts as a strata:

$$
\begin{aligned}
& \text { - Physical space } \\
& \text { - Psychological space } \\
& \text { - Social space }
\end{aligned}
$$

(Lefebvre, 1947)

Soja's elaboration of the same concept 'The Third World' as "an all- inclusive and radically open mode of defining the limitlessly expendable scope of the spatial imagination" (Soja, 1997) characterizes the alternative space re-defined by expatriates. In the movie, Kureishi's forte of characterizing Nasser's character is significant. He completely denies the physical spatiality of Pakistan and completely embraces the novice western space that led to his psychological spatiality to infuse western identifications. Nasser's succession resides in his capacity to create his psychological spatiality as an encrypted form of reality. His complete abandonment of the former world view becomes a catalyst to explore his own identity as a successful entrepreneur within the western social spatiality under the booming Thatcherian regime.

Triad of Social Space: Lefebvre triangulates three obvious spatiality of the migrants under the conceptualization of 'The Triad of Social Space'. The spatial mapping of a migrant can be seen across three geographies named native space, diasporic space and no place. Further,

\section{- Spatial practice \\ - Representation of space}

- Spaces of Representation (Lefebvre, 1947) is also taken into consideration here.

According to Lefebvre's identifications of space, Kureishi's characterizations in the West have constantly are entrapped within numerous spatiality that evidenced their migrant experience more traumatic. Their inability to identify a proper sense of belonging to a unique space had become the burden of migrants. The fluctuation in between diversified spaces had evidenced their migrant experience more hectic. In implanting himself in the western social space, Nasser recreates an alternative space more affiliated to the western locale than his eastern Pakistani self by configuring the past and present in an imaginary symmetry. In that regard he had 
to traverse through the 'representation of space' or the dominant space in the Centre that he prioritizes his material advancement and social mobility as a successful entrepreneur in the west than his native Pakistani upbringing. By traversing through the two dialects he identifies a novice perpetuation of present that completely deviates from his former roots. As per Lefebvre's 'spatial ambiguity', the amalgamation of past and present spatiality of a migrant is interconnected and Nasser had the capability to define a unique social space for himself by the complete abandonment of native roots. The specialty of Nasser's characterization resided through the way he redefined his identity while almost all the other characters are enticed to their Pakistani roots.

In the movie, the skillful characterization of Nasser and Hussein, two brothers epitomize the initial phase of migrant turbulence while Nasser had achieved prosperity with the booming Thatcherism when Hussein had characterized as a disillusioned Socialist. Both of them signify the psychological mobility of expatriates with their geographical mobility from home. Two brothers portray complete deviation from the former worldview and embraced the novel, western view yet Hussein was incapable to fully refrain from the physical space of home compared to Nasser. The movie traces Nasser's succession as a businessman and Papa as a lethargic, alcoholic disillusioned with the arrival of Capitalism. Under the booming Thatcherism, their acquisition of identity is parallel to the proprietorship of capital. Completely market-oriented disciples alike Nasser could survive in that system with his adhering to the notion of 'earn at whatever cost' which later followed by Salim and Omar.

Nasser and Omar as Survivalists in No Place: England as a country that immigrants hate and love upsizes his western space parallel to his struggle for survival in the Centre. Nasser adores England as England has the capability to relinquish his financial dream that the periphery is unable to sustain for himself. Moreover, he hates England owing to catastrophic ordeals that he has to undergo in the pathway of achieving the dream. It is merely through economic prosperity that Nasser could establish his identity in the Centre. Though he is in a way reluctant to adore England, he had to rely on the country for his survival as a Pakistani expatriate. The strategy of survival for Pakistani immigrants depended on the accuracy of 'squeezing tits of the system'. In the success story of Nasser, he had the complete faith on the new enterprise culture that negates racial-cultural polarizations. The new enterprise culture nurtured by coeval Thatcher politics, had inculcated notions of adapting any methodologies of either legal or illegal to earn money that comparatively advocated by Nasser, Salim and later by Omar. In his journey of excavating his desired space in the west, Nasser embraces the Thatcherian market economy that derives an opportunity to implant himself in the physical space of London and his psychological realm as a successful entrepreneur.

'I’m a professional businessman not a professional Pakistani. And there's no question of race in the new enterprise culture.'

(My Beautiful Launderette, 1985)

Nasser traverses to the extent to objectify a White, European female, Ratchel in his expedition of migrant spatiality in the west. Nasser's extramarital rapport with Ratchel is a part of his survival in the west. Ratchel, a British, European female essentially characterizes immigrants' notions of the 'western fantasy woman'. The sexual episode of Nasser with Ratchel manifests the European erotica that Nasser was unable to derive from Bilquis, his Pakistani spouse. On the other hand, in order to survive in the novice European locale, Ratchel was a strategy to implant himself and attribute recognition amidst the European majority that elaborates Nasser's capacity to traverse into any end in his pathway of survival. Kureishi's expatriates fluctuate between survivals and values that they upsize survival over values, as survival is extremely significant in excavating their place in the west. It is obvious that Nasser advocates all strategies to reclaim his space in the Centre.

The way Nasser manipulates Johnny as a dupe for the removal of unpaid tenants in his housing complex is reminiscent of his extent of his embracing of western identity. The person was poor and a disciple of Pakistani origin who hardly survived in the west. As Nasser was not a person who attributes emotions over money, he throws away the person and his luggage using Johnny. Even though the person affiliated to his native roots in Pakistan and undergone the similar plight that Nasser had come across at his initial phase of migration, he does not accommodate sentiments over money as an epitome of a professional businessman rather than a professional Pakistani. The endless parties at Nasser's home, which was a reunion of Pakistani immigrants, resemble themselves as a microcosm of the macrocosm of coeval Britain. Their parties, different varieties of alcohol and drugs with money articulates the masculine excitement about the newly acquired wealth and the new land. In the new entity, Kureishi's expatriates granted the opportunity to own wealth that they have never acquired in the native territory. The breach in Ratchel's rapport after Tania's accusations of spending her father's money lavishly and Tania's exodus from the immediate backdrop, Nasser was in a way disappointed yet not ready to welcome the idea about the impossibility to relinquish identity as immigrants in the west. However, Papa manifests his disillusionment regarding the migrant fantasy and results of migrating to the center, while Nasser is unable to realize his self-amidst his success with Capitalism. Although Papa symbolizes his western space in the Pre- Thatcher society, the socio-political consequences of Thatcherian economy had paved the way to rethink about his authentic space in the Centre. While Papa identifies their inability as expatriates to generate a homely feeling in the west, Nasser upsizes a pool of wealth that Capitalism gifted for his hard work and self-reliance in the center that portrays his eastern objectivity in relinquishing his financial dream and identity in the Centre. It is obvious that Nasser was devoid of multiple heterotopias in him that generates his establishment of psychological stability with the physical geography. His negotiation with the novice space resembles his ability of reconciliation in the new entity. Nasser's fluctuation between immoral strategies of acquiring capital by negating values had juxtaposed with the urge to require such mobility in his pathway of the complete deviation from the former space.

Hussein: 'Listen the damn country has done us in. That is why I am like this. We should be there home.

Nasser: But that country is sodomized by religion. It is beginning to interfere with the making of money. Compared with everywhere, it's a little heaven here.'

(My Beautiful Launderette, 1985)

In comparison, Hussein's character is a partial resemblance of the identification of his migrant fantasy with his disillusionment regarding the impossibility to survive in the realm of Capitalism. The movie juxtaposes Hussein's prosperity in 
Pakistan with his struggle to assimilate in the west. In Pakistan he was a book-learned journalist with alliances to popular politicians in India yet as per Salim's articulation to Omar, Hussein's socialist ideals and his prosperity in the east is futile in the west without the acquisition of wealth. As per Nasser, Hussein upholds European ideals with his western attire and habitual demonstrations but he negates western notions, which are outbursts of Capitalism. As an instance, though he downsizes western Capitalist notions, he grants the support of Nasser, who is an advocator of Capitalism, in search of a possible vocation for his son, Omar. In that moment, he requests Nasser about prospects of marriageability to Omar with a nice female of Indian origin, exemplifies his deep-rooted nostalgia towards the former physical space. Papa's exposition of the Indian origin exemplifies his inculcated nostalgia towards the east. Papa was in an urge to fix Omar up with his own tribe and origin, as there is a tendency for Omar to entice towards a British female. The inculcated notions of the conjugal rapport to an Indian female is reminiscent of Papa's concealed identifications of the impossibility to consider the west with a homely feeling. The west was an alienated land for migrants that they temporary reside in to gain their respective financial dreams. On the other hand, Papa inwardly believed the futility of considering Britain as a melting pot, because of the coeval socio-political upheavals. The decadence of Leftish movement is reminiscent through his alienated room and consumption of alcohol with his complete dependence on his brother for money.

Hussein's identification of education over Capital manifests his radical characterization. He believed the success of Omar not through the way of business transactions but as an intellectual. The fantasy of Papa is completely dependent on education that is a signifier in the modern world. Papa inclined to upsize Omar, not just a surviving male in London, but also an educated enlightened being that derives a sense of permanency than the acquisition of capital. In the process of acquiring their migrant fantasy, when Nasser identifies the process the money-making as the convenient pathway to establish their identity and recognition in the Centre, Papa upsizes education as the true mobilizer. Papa's character is an epitome of the fluctuation of expatriates amidst multiple spaces that made the migrant experience more traumatic. Migrants' were devoid of a proper identity either in native Pakistan or else in the west that they entrapped within cultural heterotopias. He manifests his concealed notions about expatriates' inability to acquire the position of the master land without recognizing themselves as intellectuals than seekers of money alike underpants cleaners. Hussein identifies his Marxist ideologies in the portrayal of intellect with the critical ability to witness the plight of immigrants. He further utilizes that, merely through the ideological knowledge and visionary ability to depend on education expatriates can excavate a unique identity for themselves and it is not blindly entrapping into illegal means of acquiring wealth as the mere pathway to achieve success as an immigrant.

Nasser, Omar and Salim epitomize Thatcherian economic upheaval that totally depended on an individual strategy of succession not as a communal effort. Omar was characterized by Kureishi as the successor of Omar, yet there were instances that he was entrapped in the dual spaces of Pakistan and west. Their capability to fully embrace the novice western spatiality differs themselves from other characters devoid of identifying themselves in the coeval society.
Kureishi's exposition of Omar's characterization as a versatile and dynamic expatriate eager to climb up the social hierarchy with the acquisition of money elucidated in the culmination of his identification of western self. Omar fully embraces the west like Nasser by the complete abandonment of his Pakistani roots. Omar's employment under Nasser's supervision incorporated himself as a dupe of Nasser by emphasizing capital over education. As a second-generation immigrant, he was refrained from tangible experiences of the native locale yet his enthusiasm to grant knowledge about the motherland manifests his concealed identifications of the east. By travelling through the pathway of money-making, he climbs up the ladder systematically, initially by cleansing cars, an accountant to a proprietor of a launderette. Omar envisioned transformation in his life and status that upsized Thatcherian notions of individual effort to gain prosperity. By granting Nasser's vocation, Omar gained the opportunity to transgress into the new world to acknowledge the process of earning money.

Kureishi's implication of launderettes as a center of intermingling minorities manifest conflicts and possibilities parallel to the contemporary socio-political locale. Omar's identification of the launderette as a pool of wealth that prosper his future, initiates a method of expansion with his gay partner Johnny. At the initial phase, he becomes the intermediary of drug dealings even though physically abused by Salim. Omar's independent and challenging inclination to steal Salim's narcotics to raise funds to renovate the launderette his drastic desire for the acquisition of capital is a phase of his identification of capital as the mere strategy of survival in the west. Omar's first encounter in the movie of washing Papa's clothes in a sink and pull clothes on a cloth line with his transformation as a proprietor of a launderette is reminiscent of any possibility with Thatcher's economy. The employment of Johnny to interact menial activities in composition with stealing Salim's drugs, renovating the launderette and later stealing a house to raise back money for the stolen narcotics of Salim articulates the exploitation under Thatcherism. Like Nasser, Omar becomes an upholder of power with the acquisition of money from the launderette. Omar's manifestations in securing his migrant fantasy espoused in a way of his re-creation of in-between comfort zone while traversing through a Capitalistic journey in acquiring capital in granting recognition in the alien land, he investigates about his Indian- Pakistani roots, from disciples of the first generation. He constantly interrogates Nasser and Cherry about Karachi that is reminiscent of his difficulty to explore his space as a second-generation immigrant.

In the movie, the launderette functions as a catalyst for the continuity of the homosexual relations of Omar and Johnny. Omar's complete recognition of the European ideals, reinforced through the rapport that was devoid of Pakistani origin and he was a dominant homosexual male rather than a female by being the counterpart of Omar. In the process of Omar's survival as a second-generation expatriate, in a way his homosexual relations towards Johnny exemplifies dynamics of their romantic rapport, as a master and a slave as well as lovers. The manipulation of Johnny's romantic relations to engage himself in diversified menial works articulates Omar's exposure towards the new- enterprise culture and his ability to objectify a White, European.

'I saw Salim's game. This is going to finance our whole future. This means more. Real work. Expansion.'

(My Beautiful Launderette, 1985) 
The catchy title of the movie portrays Omar's proprietorship in the entire regime of wealth. The personal pronoun ' $M y$ ' is devoid of Nasser's ambitions of profits financed by Salim's narcotics and partnership with Johnny than Omar being the mere proprietorship of the launderette. According to the researcher, Omar's renovation of the launderette with Johnny by the employment of cleansed machines, neon lights and candy colors epitomize Pakistani expatriates' fantasized dream in the center.

"Space used to be either dismissed as belonging to nature; that is the given, the basic conditions of 'Physical geography'. In other words, a sort of 'Prehistoric Stratum' or else it was conceived as the residential place or field of expansion of peoples, of a culture, a language or a state."

(Foucault, 1986)

The Location of the Female: As per Foucault's conceptualization, Kureishi's female characterization in the movie is reminiscent of the females' incapability to identify their psychological space in the Centre with the physical mobility. The plight of female subjects in the diaspora addressed by Kureishi as the female exclusion from the masculine success journeys in the west. The borders of migration of expatriates from east to west negated female diasporic subjects that reflected in a way of their passive reaction to the new western space. It is authentic that, compared to masculine counterparts, females' inability to bridge the gap between history and memory with the present physical space inherited to them with the process of migration, they were unable to nourish third space as a comfort zone for themselves. Yet, their nostalgia to the past and deep-rooted enticement to the native territory become a catalyst for the fluctuation of themselves within both physical entities.

'Immigrants want a new life and the material advancement that goes with it. But having been ripped from one world and flung into another, what they also require.... Is tradition, habitual ideas and statis.'

(Hanif Kureishi, 1986)

In 'My Beautiful Launderette', Kureishi voices the female counterparts' incapacity to deviate themselves from the former social formation.

"In course of these productive negotiations, the familiar geographies of 'home' and 'identity' reveal their inherent social constructedness and undergo a process of imaginary re- mapping."

(Chackraborthy, 2011)

Kureishi manifests the female's inability to re-define their identity in the novice physical space through Bilquis, Tania and Cherry. Bilquis's introduction of Omar to a flock of aunties resides in the living room is juxtaposed with Nasser's room full of males. The scene generates the polarization of males and females in which males are overwhelmed by their newly achieved success in Europe while females were contemplating on their native roots in Pakistan. On the other hand, Kureishi's cinematic effect exemplifies patriarch's ability of the fully abandonment of the former world view with the geographical mobility while females are enticed to the Pakistani space. The idea is reaffirmed with Cherry's reference to Karachi as her locale of permanency and her desire to reside in Karachi every day and her downsizing of Omar's consideration of Britain as his motherland. Their migration to the west with their respective male counterparts to the 'land of plenty' for the acquisition of capital had completely excluded females.
'I know all your gorgeous family in Karachi.... It is my home. How could anyone in right mind call this silly little land off Europe their home? Every day in Karachi.'

(My Beautiful Launderette, 1985)

The powerful evocation of female gaze point to generate the idea of migration as a gendered experience utilized through the cinematic effect of placing female gaze behind doors and windows of their domestic spheres. Kureishi's forte of the implication of female gaze point employs the idea of one generation holding the ethical doubt regarding the entire scenario of migration. Females' fluctuation between the masculine counter-parts financial dreams vs inculcated roots of the east. While the mobility of periphery had become a catalyst for the acquisition of the progress in professions and accumulation of wealth for males while females undergo drastic traumas of migration. Bilquis's gaze point is projected when Salim and Zaki were drunk and making chaos outside the residence. Bilquis's gaze point manifests the masculine excitement regarding the acquisition of wealth that is reminiscent of their superficial enjoyment out of loss. In the journey of wealth accumulation Pakistani expatriates undermines their unique identity and Pakistani self. In the movie, when Tania inquiries from Omar regrading Nasser's mistress Ratchel, Bilquis's gaze point is employed by Kureishi to voice female's misery in the Centre. The female counterpart who had sacrificed her entire life to the extent of migrating herself with Nasser is abandoned in Nasser's exploration of spatiality in the west. It exemplifies the way females are excluded from the success stories of males that they were devoid of any suitable strategy to absorb themselves to the Centre.

Bilquis's employment of superstition to regain Nasser back portrays her enticement to the native land. Her returning to superstitions and gods reminiscent of the deadlock of modernity. When modernity is unable to pursue desires of individuals, they traverse back to the past that is the true existential crisis. The evocation of superstition by Bilquis upsizes her mere desire to regain Nasser back to sustain the family that she cherished back from Pakistan. The female counterparts' traditional attires like Shalwars depicts their ordeals of diluting deep-rooted Indian roots. Bilquis's decision to return back to Pakistan articulates the notion of migration as a gendered experience that females' inability to amalgamate themselves in the novice backdrop like males owing to their nostalgia to the east.

Moreover, in the moment at Nasser's home, when Cherry reveals her disappointment over Omar, her own in- between identity is upsized. Her identification of England as a temporary destination and Karachi as the homeland utilizes her traumatic identity.

'the feeling of nostalgia is infused with implications of past beauty, pleasure, joy, satisfaction, goodness and the positive aspect of being.'

(Bhabha, 1986)

Tania's characterization depicts the notion of females' quest for physical and psychological space in the western locale. In a way through her exodus, she rebels on the female subjectivity as a sacrifice at the verge of queer diasporic subjectivity.

'Tania is structurally marginalized because she does not conform to the accepted role of women in both cultures and she cannot be accommodated by the film.'

(Ranasinghe, 2000) 
In her journey of survival, marital rapport to a prospective partner, either Pakistani or European was the mere way-out for her. She is devoid of necessary skills or vocational attributes to assimilate herself to the booming Thatcher economy. As her father, Nasser was not an advocator of enlightenment through education; marriage was the mere strategy for Tania's survival. As a female entrapped in the circle of migrant turbulence, she flirts with Omar and Johnny. Her attempt of showing her breasts to Omar is the first phase of her sexual manipulation. In that moment, apart from Omar, the drunkard Zaki witnesses Tania's breasts and dilutes his projection of her breasts as a mere hallucination of intoxication. Zaki's reaction is highly symbolic about the way females undermined through the gaze point of males. Her continuous sexual manipulations were not productive with her realization of Omar's homosexuality that transfers her manipulations to Johnny. The way she was cycling with Johnny in the rain at night was the peak of her sexual manipulations. It is obvious that though Omar was a homosexual, he flirts with Tania that is a part of his objectification. Tania's realization of Johnny - Omar homosexual rapport with her disoriented family ties, her mere choice was withdrawing herself. In the opening ceremony of the launderette, her requesting of financial assistance from Omar exemplifies her struggle. Moreover, her attempts to persuade Johnny to leave with her reinforce the inability of herself to sustain as a female amidst the migrant turbulence.

Tania's exodus is a powerful evocation of the uncertainty of her future like the present in the entire scenario of expatriates'. As Kureishi's movies are viewed through a male-point of view, Tania's future is untold to the audience. She was not an epitome of passive, de- sexualized being and challenges hegemonic ideals. It can be identified as a female sacrifice at the verge of queer diasporic subjectivity. The exodus viewed by Nasser and Hussein amidst trains manifest the authentic idea of migration, that females are devoid of any capacity to adjust themselves to the process of migrations.

'I need to leave home. I need to break away. You need to help me financially.'

(My Beautiful Launderette, 1985)

The forte of Hanif Kureishi to upsize catastrophes undergone by migrants to identify their own physical spatiality of migration from periphery to the Centre with the psychological space of embracing western identifications had upsized with the gender differentiations. Disciples alike Nasser and Omar were devoid of a heterotopia of the self that they completely adhered to the western self-offered by the physical space. The journey of excavating the psychological spatiality of migration was hectic for females owing to their nostalgia to the past self and memories. Due to the incompatibility of migrants' real space conflict with alternative spaces derives their inability to traverse beyond their psychology creating a new entity. In a broader spectrum, by employing Edward Soja's Marxist approach on spatiality, the researcher acclaims the conceptualization of the 'Cultural Heterotopology' in the movie. The transition of migrants' physical space from Pakistan to London could accommodate the psychological space for characters like Nasser and Omar that they could implant themselves in the novice social space. Yet, female counterparts were devoid of infusing themselves in the physical space of the west that was completely enticed to the given cultural geography of Pakistan.

The Influence of Thatcherism over the Traumatized Psychology of Pakistani Expatriates: Margaret Thatcher's ac- quisition of power with neo-conservative policies that interlaced with the free market economy exposes individuals' need of hard work and self-reliance for the acquisition of capital. Capitalism completely boosted disciples who had the mere faith on monetary prospects. Kureishi's location of South Asians amidst the controversial backdrop of the Thatcher government utilize catastrophes encountered by expatriates in the Centre. The extremist facade nurtured by the pretentious fear among the British majority that the 1960 immigrant flux to Britain has a tendency to invade the population of British majority in the coming future. The culmination of racial-cultural polarizations account for the upheld of the National Front League and Skinhead movement that Johnny becomes a part and later the Islam fundamentalism depicted by Farid's characterization in 'My Son the Fanatic'. The Great Miners' Strike was a part of the social upheaval that led to the outburst of unemployed working-class articulated by Johnny, Omar and Genghis.

Expatriates' succession in the booming Thatcherian economy alike Nasser, Omar, Salim in 'My Beautiful Launderette', Haroon in 'The Buddha of Suburbia' and Parvez in 'My Son the Fanatic' are instances of the employment of opportunistic regulations of immigrants in the west. By the attempt of assimilating South Asian immigrants to their acquisition of the financial dream in the west, indirectly entrapped expatriates as mere dupes of the Thatcher government. Nasser, Omar and Salim are ideal personas nurtured by the Thatcherian economy that believed in hard work than the state. Nasser's succession as an entrepreneur in the west as he completely abandons his former worldview and embraces the Thatcher economy that supports him to realize his financial dream in the west. The way Salim and Nasser's employment of narcotics is an outcry of coeval economic agenda that articulated notions of 'earn at whatever cost' legally or illegally as the proprietorship of monetary prospects was the mere strategy of survival for immigrants in the west. The authentic facade of the acquisition of power and capital under Thatcher effectively portrayed Omar's evolution from unemployment to a business adviser nurtured by the financial dream of the proprietor of 'Ritz of launderettes'. In his journey of success, he smuggles Salim's narcotics and even robs a house to play back Salim's money. The depiction of migrants as epitomes of both power and money is a reaction of Thatcherian economy. Nasser's rapport with Ratchel, a European female is a part of his opportunistic nature of granting status and popularity among the British majority.

The upcoming power of Thatcher upsizes on uncertainty for racial- cultural marriages and offspring.

'Racism goes hand in hand with class inequality. Among other things, racism is a kind of snobbery, a desire to see oneself as superior culturally and economically and a desire to actively experience and enjoy that superiority by hostility or violence.'

(Kureishi, 1986)

The policy of privatization under the free market economy had the capability to withdraw unemployed homeless tenants visible at the preamble of the movie through the removal of Johnny, Genghis out of a dilapidated building reminiscent of industrial past. Moreover, Nasser's employment of Johnny to remove unpaid tenants of the building is a part of this privatization.

The radical hostility on expatriates fostered by the Thatcher economy upsized in all three movies. In 'My Beautiful Launderette' Johnny's participation of the national Front League 
and the Skinhead movement with slogans of 'immigrants out' voices the coeval resistance for colored immigrant flocks. Johnny's participation for the March is the initial reason for Papa's disapproval of Johnny. The movie voices many native- white Britons economically distorted and unemployed as a result of the Great Miners' Strike that exemplified with the conversation between Johnny and Genghis.

Johnny: 'You're getting greedy.

Omar : I want big money

Johnny: I am not gonna be beat down by this country...

Omar : What you do? Washing my floor.'

(My Beautiful Launderette, 1985)

The quotation elaborates the undermining of expatriates nurtured by the political antagonism. The initial refusal by Genghis to Salim, by removing his pants resulted in Salim's smashing the car on one of the members of Genghis's troop. The final fight in between Genghis's troop and Salim, that completely smashed Salim's by wounding both parties are reminiscent of the vengeance fostered by the Thatcher regime regarding the economic prosperity of the immigrants in the west. The introduction of Pakistanis as 'Paki' is a part of the linguistic discrimination on expatiates.

'I don't like to see one of our brooks groveling to Pakis. They came over here to work for us...

Don't cut yourself from your own people. There's no one else who really wants you.

(My Beautiful Launderette, 1985)

Margaret Thatcher's political testimonies of the capacity of Socialism to inculcate aspirations on individuals to depend on the state without granting responsibilities of themselves and their families is characterized through Papa in 'My Beautiful Launderette' Papa's character upsizes as a disillusioned Socialist and an alcoholic enticed to the Pre-Thatcher notions. His juxtaposition capital with education challenges the temporary satisfaction of money than intellectual pursuits. Papa's desire to nourish Omar out of intellectual pursuits rather than an underpants cleaner voiced education as a signifier of the modern world. The fantasy fostered by Nasser under the Thatcher market play undermined with Socialist ideologies of Papa. Papa's desire to uplift Omar as an enlightened being in London had trampled over Omar's entrapment of Nasser's exposition of Thatcher's economy. Papa's unemployment portraits the immigrants' plight of unemployment who opposes capitalistic views.

The improvement of regulations on sexuality challenged by Kureishi by creating his protagonist as homosexuals, bi-sexual and individuals pursuing extra-marital rapports. Omar's homosexuality with Johnny and Nasser's adultery with Ratchel upsizes as identifications of Kureishi's scathing criticism on Thatcher regime. The intermingling of cultures that derive the notions of accommodating discrepancy is rather the ongoing need of the coeval politics. In a way, Kureishi's introduction of Britain as a melting pot with the welcoming of different racial- cultural inequalities through sexual relations, manifests his sardonic remarks on the hegemonic identifications of race, sexuality and gender that upheld by the neoconservative policies authorized by the Thatcher regime. The cinematographer's refusal of Thatcher's conceptualization of 'Oneness' had manifested that nurtured superiority of the British majority while undermining other Asian cultural identities in Britain.

The traumatic experiences of his inability to identify themselves in the Centre despite his western upbringing utilizes as an extended version of the sense of not belonging and
Aloofness incorporated by the first-generation immigrants. Moreover, the psychological trauma of uprooting themselves from host locales and implanting themselves in the challenging catastrophic west and its cultural prejudices hosted by contemporary Britain had concluded for immigrants to partake in racialized antagonism against the British majority. The wounded psychology upsized and their rejection of the possibility of assimilation of the two cultures portrays the realization of marginalization.

It is obvious that the marginalization imposed under Thatcher had manifested by Kureishi in dualistic connotations.

\section{The National Front moment in 1980}

2. Religious violence in cooperated with Islam fundamentalism

It is obvious that the adverse impacts of marginalization imposed under Thatcher had reacted to both native underprivileged Britons and expatriates. This dualistic connotation manifest about the inability and unwillingness with the disapproval inculcated on the majority that is reminiscent of their inability to realize the existence of diversified identities and the necessity to assimilate immigrants of diversified unique character-traits in the west. Kureshi's depiction of the rapport between the authenticities of individuals with their ideologies, cultural, political religious identification. is a part of their identity game.

'The real differences in Britain today are not political or even based on class but they arranged around race and religion with their history of exploitation, humiliation and political helplessness.'

(Kureishi, 1986)

Kureishi's quotation manifests the trampling of the first-generation immigrants who had the tangible experience regarding the hegemonic identifications of the White master. The second generation had deviated from the tangible experiences that were accounted by the first-generation immigrants during the epoch of 1960's immigrant flux. Second generation expatriates are in an expedition to carve an identity, space for themselves in the West that resulted in further traumatization of them. The opportunistic implications of Powell and Thatcher's political notions that simultaneously include and exclude South Asian to infuse in to the hegemonic discourse, in a way the opportunistic politicians had invited immigrants to the west as workforce by erecting a utopia of the Centre as the ideal place for the acquisition of their financial dream. In the same way, they were harboring notions of antagonism among the community with the refusal of the expatriates as invaders of Britain.

Kureshi's forte of cinematography manifested in selected movies: the ongoing clash between Genghis's troops with Pakistanis, catastrophes encountered by other expatriates in upsized to a culmination of racial politics nurtured by Thatcher. It is obvious that expatriates' exploration of physical space with the socio-cultural spatiality had challenged the outburst of political upheavals in coeval west.

\section{CONCLUSION}

Hanif Kureishi's forte of upsizing deep- rooted identifications of migrant spatiality manifests expatriates' entrapment within contours of their desire for wealth accumulation and the identification of unique self that held in a drastic crisis. The struggling attempts of Pakistani expatriates to infuse themselves amidst the British majority is in conflict with their consideration of the west as the land of plenty. 
In the journey towards progress success in a neo-liberal Thatcherian land, expatriates mimic the colonial master who already reached the benchmark of superiority of the west as epitomes of succession that inflamed the notion of migration. They were supposed to adapt according to European values and be forced to abandon memories of their original homeland. That transformation to modern spatiality was required from every individual who dreamt of individual success. In each and every possible way, migrants objectify themselves by embracing western identifications optimally by negating their eastern upbringing. Kureishi reinforces the crisis of Pakistani immigrants' in the fluctuation between dualistic spheres. Although, disciples overwhelmed by the acquisition of capital and power in the west, their incapability to grant an identity in the host country had become a catalyst for the psychological dilemmas of expatriates.

The selected sample upsizes the fundamental question whether the territorial shift from periphery to the Centre, had the capability to overcome expatriates traumatized inner self. Acculturation and adaptation to the novice locale upsizes as an outburst of trauma as it was offensive and catastrophic for immigrants. Although they penetrate their convenience of embracing western space, they uproot themselves whenever they grant an opportunity to reside in their native space that is reminiscent of their fluctuation in both spaces. Females' incapability to assimilate to the west as they upheld deep-rooted nostalgia to the host backdrop than males. Yet in a way Kureishi exposes their enticement to the past, native upbringing with their emotional downfalls that erected the migrant spatiality more hectic.

The researchers encountered novice findings that concealed in the exploration of migrant spatiality. Pakistani expatriates' fluctuation in between multiple sexualities are parallel to their explorations of unique identity and self in the migrant phenomena. Immigrants' incapability to identify themselves to the dominant heterosexuality and extra marital rapports depict the identity crisis and the sense of not belonging. In a way, multiple sexual orientations voice their escapism from the socially accepted hegemonic gender identifications with their physical territorial shift from one territory to another. Moreover, the researcher encountered the drastic influence of coeval socio-political upheavals on immigrants as a catalyst of dilemmas of migration. Marginalization and prejudices nurtured by Thatcher and other racialized politicians alike Enoch Powell, harbored polarizations amidst natives and immigrants that boosted their political upper hands.

In the pathway of identifying migrant spatiality of immigrants as a portrayal of their traumatized psychology, the researcher detected Hanif Kureishi's tangible account through the reversing of master-slave dialectic in the selected sample. It upsizes a fundamental inquiry on the possibility of granting identity for Pakistanis in the Centre. As a portrayal of the psychological payback of the colonial legacy, the master's domination of the periphery had reversed in a way of Pakistanis domination of native Britons. The reversal of the master to a slave had to account as an embodiment of the inner quest of unique spatiality by the colonized through residing in the territories of the colonizer. In theoretical implications Edward Soja's conceptualizations on the Third Space and Henry Lefebvre's depictions on spatiality can be effectively positioned on diversified arenas further to elaborate migrant experience of expatriates' in the West.

\section{REFERENCES}

Athanasiades. A. (2017). The Identity of "Paki" versus "Pakistani" Engendering Power Boundaries in Hanif Kureishi's My Beautiful Launderette. Advances in Social Sciences Research Journal, 4(3). 23-50. DOI: https://doi.org/10.14738/assrj.43.2670

Athanasiads. A. (2013). Re-imagining desire and sexuality in the cinema of Hanif Kureishi. University of Cyprus, DOI: https://gnosis.library.ucy.ac.cy/bitstream/handle/7/38987/Andreas\%20Athanasiades\%20PhD.pdf?sequence=4\&isAllowed $=y$

Balaev.M, (2014), Contemporary Approaches to Literary Trauma Theory, UK: Palgrave Macmillan.

Bhabha. H. K. (1994). The Location of Culture. Routledge Classics. Volume 55.

Chakraborty. Sudipta, (2011), Space and cultural geography: A study of V.S. Naipaul's representation of India in his travel narratives, India: Budwan University.

Dyer, R. (2002). Dirty work, Asian entrepreneurship, and labors of love in Hanif Kureishi's My Beautiful Launderette. In Critical Sense, 10(1), 59-86.

Fanon, F., \& Farrington, C. (1994). Black Skin, White Masks (31616th ed.). Grove Press.

Foucault, M. (1990). The History of Sexuality, Vol. 1: An Introduction (Reissue ed.). Vintage.

Foucault, Michel. (1967) "Of Other Spaces". Trans. Jay Miskowiec. Diacritics 16 (1986): 22-27. Trans. of "Des Espaces Autres". ArchitectureMouvement Continuité.

Frears . Stephen (Director). (1985). My Beautiful Launderette, [Channel four films].

Hapugoda, M., 2016. Failures in Decolonization and 'the Return to the Past: Reading V.S. Naipaul. Sabaragamuwa University Journal, 14(1), pp.59-86. DOI: http://doi.org/10.4038/suslj.v14i1.7692

Kureishi, H. (1986). My Beautiful Launderette and The Rainbow Sign (First Edition). Faber Faber Inc.

Lefebvre, Henri, \& Nicholson-Smith, D. (1992). The Production of Space (1st ed.). Wiley-Blackwell.

Maxley, Ruth, (2006), Life in the Diaspora is Often Held in a Strange Suspension: First-Generation Self-Fashioning: Hanif Kureishi's Narratives of Home and Return, The Journal of Commonwealth Literature, 41(3) pp.5-25. DOI https://doi.org/10.1177/0021989406068732.

Michell. Roger (Director). (1993). The Buddha of Suburbia, [ BBC Films].

Moore-Gilbert, B. (2002). Hanif Kureishi (Contemporary World Writers) (1st ed.). Manchester University Press.

Prasad. Udayan (Director). (1998). My Son the Fanatic, [ Channel four films].

Ranasinha, R. (2007). South Asian Writers in Twentieth-Century Britain: Culture in Translation (Oxford English Monographs) (1st ed.). Clarendon Press.

Said, E. W. (1994). Culture and Imperialism (25447th ed.). Vintage.

Soja, Edward. (1989). Postmodern Geographies: The Reassertion of Space in Critical Social Theory. London: Verso, Jaipur \& New Delhi: Rawat Publications.

Thatcher. Margaret, (1993), The Downing Street Years, London: Harper Collins.

The Immigration Act, S.358, 101 congress (1971).

Young, R. J. C. (1995). Colonial Desire: Hybridity in Theory, Culture and Race (1st ed.). Routledge. 
